\title{
Educational Attainment and Educational Mismatch in the First Employment in Spain
}

\author{
Marta Rahona-López and Carmen Pérez-Esparrells \\ Departamento de Economía y Hacienda Pública, Universidad Autónoma de Madrid, 28049 Madrid, Spain
}

Correspondence should be addressed to Marta Rahona-López; marta.rahona@uam.es

Received 17 February 2013; Accepted 19 March 2013

Academic Editors: K. Kingsley and E. M. Skaalvik

Copyright ( 2013 M. Rahona-López and C. Pérez-Esparrells. This is an open access article distributed under the Creative Commons Attribution License, which permits unrestricted use, distribution, and reproduction in any medium, provided the original work is properly cited.

This paper analyses the labour market entry of Spanish school leavers and the match between education and work at the early stages of working life, using a specific data set drawn from the Spanish Module Education to Labour Market Transitions (2000). Special attention is paid to university graduates, because Spain experienced a strong growth in the demand for higher education during the last decades of the 20th century. The empirical evidence shows that although over-education is a common phenomenon in the Spanish youth labour market, being a graduate seems to be associated with a lower likelihood of over-education in the first job. Our results indicate that over-education affects more women than men and foreigners than Spaniards.

\section{Introduction}

The seminal empirical works focusing on the study of educational mismatch date back to the early 1970s, when this problem and its consequences were detected for the first time in Canada [1] and in the United States [2]. Since then, several researchers have analysed the scale and the impact of educational mismatch in different developed countries. The results of these studies show that a percentage of the employed population presents a mismatch between their educational attainment and the level of studies required in their job [35]). Two types of educational mismatch have been identified: overeducation, which occurs if a worker has excess education to do his/her work, and undereducation, which results in workers not having enough education to do their job.

Although the literature on mismatch in the labour market is quite extensive, studies focusing only on young people and devoted to analysing the influence of socioeconomic variables on overeducation in the first job are not very abundant. For instance, Allen and van der Velden [6] examine the labour situation of Dutch youngsters, and they find that more than $40 \%$ of young white men are overeducated at the beginning of their working life, whereas only $13.6 \%$ of them present undereducation in their first employments.
There are several papers which focus on studying the problem of overeducation among graduates in the United Kingdom. For instance, Battu et al. [7] find that more than $40 \%$ of graduates have a job which does not require a degree, one year after graduation; the results by Dolton and Vignoles [8] also show that about $38 \%$ of graduates were overeducated for their first job; Chevalier and Lindley [9] investigate the effect of the graduate expansion on early labour market attainment; their results show that about $35 \%$ of British graduates are overeducated seven years after their graduation. More recently, Dolton and Silles [10] find that approximately $43 \%$ of British graduates reported being overeducated for their first job when overeducation is reported as the educational qualifications to obtain the position. However, when overeducation is defined as the educational qualifications required to do the job, the incidence rises to $55 \%$.

In the case of Spain, there are some researches that have analysed the incidence of overeducation among young people. Taking the data from the Encuesta Sociodemografica, conducted in 1991, Lassibille et al. [11] analyze the labour market entry of Spanish school leavers and the match between education and work at the early stages of working life. The empirical evidence shows that mismatches between work and education appear to be more frequent among new 
entrants in the labour market than among more experienced workers, and according to their results more than $42 \%$ of young workers are overeducated in their first job. However, only 3\% of Spanish young people are undereducated in their employment. In addition, regressions results indicate that people with higher education have, all else being equal, a lower probability of being overeducated. Finally, the work of Garcia-Montalvo and Peiro [12] reports that $42.3 \%$ of Spanish young people have attained a level of education that is higher than the education required to do their first job, whilst the proportion of undereducated is $1.5 \%$.

In order to contribute to this literature, the current study is focusing on the first labour stages in an individual career and analyses the match between educational attainment and the first employment obtained. The paper proceeds as follows: Section 2 briefly describes the data and variables included as well as the econometric method used; Section 3 presents the most important results obtained in the empirical analysis; and Section 4 contains the main conclusions.

\section{Methods}

Empirical results are based on data from the ad hoc Module on School to Work Transitions, included in the 2000 second quarter Spanish Labour Force Survey and conducted by the Instituto Nacional de Estadistica (INE). The module consists of 14 additional questions designed to provide information on two main issues: the maximum educational level attained and the achievement of the first significant job by Spanish youths. The sample covers about 15,000 individuals aged from 16 to 35 who have left education for the first time in 1991 or afterwards. This source of data makes it possible for researchers to grasp the main features of the school to work process in the 1990s and enriches the already existing information for the study of youth entry in the labour market.

The literature distinguishes three types of measures of job mismatch, based on the degree of the adjustment between job requirements and workers' qualifications: objective, subjective, and statistical measures. The objective measures quantify the level of mismatching by comparing the level of education attained by each worker with an independent scale of requirements for each occupation $[11,13,14]$. The subjective measures determine the level of mismatching by comparing the level of education attained by each worker with the worker's opinion regarding the qualification required to perform the job properly [5-7]. Finally, the statistical measures estimate the level of mismatching by comparing the level of education attained with the mean or the mode value of the years of education within each occupational category. This third method has been applied by Verdugo and Verdugo [15] using the mean approach and by Kiker et al. [16], Cohn and $\mathrm{Ng}$ [17], Mendes de Oliveira et al. [18], and Bauer [19] using the modal approach.

In this paper, the mismatch between education and work is measured by using a modal-based statistical measure which is used to estimate years of required, over- and underschooling. More than sixty occupations corresponding to the two-digit occupational code proposed by the National
Occupational Classification (1994) are considered when estimating educational (mis)match. Years of required education $\left(S_{r}\right)$ correspond to the modal value of years of schooling for those individuals who are appropriately educated in each occupation, whereas years of over- and undereducation $\left(S_{o}\right.$ and $S_{u}$ ) are given by the difference between the actual years of schooling and the modal value in each occupation for over- and undereducated workers, respectively. Therefore, we define a worker as being overeducated if his/her years of education are above the modal value of his/her job. Likewise, a worker is undereducated if his/her years of education are below the modal value of his/her job, and finally, adequate workers are those whose years of education just match up with the modal value of their jobs.

The empirical strategy adopted here aims to estimate three possible indicators of labour market outcomes. We have adopted a multinomial logit model with three alternatives: being adequately matched in the first significant job, being overeducated, and finally being undereducated in the first employment.

The model can be motivated by a utility maximisation problem: in this case, the individual derives some utility from his/her labour market status (overeducated, undereducated, and adequate) which is denoted by $U i j$ and is a function of personal attributes, represented by $X i j$ like variables indicating human capital and some external covariates (family background, business cycle, place of residence, etc) as follows:

$$
U i j=X^{\prime} i j \beta+\varepsilon i j,
$$

where $\beta$ is a vector of coefficients for the different explanatory variables. The probability that shows the first labour market outcome that is achieved is given by

$$
P\left(y_{i}=j \mid X\right)=P_{j}=\frac{e^{X^{\prime} B j}}{1+\sum_{s=1}^{J-1} e^{X^{\prime} B s}} \quad \forall j=0,1, \ldots, J,
$$

where $j=1,2$, and 3 refers to the three different possible values of the dependent variable, $X$ refers to the vector of covariates, and $\beta j$ is the vector of coefficients linked to the explanatory variables.

The dependent variable takes value 0 (reference) when the interviewee's level of education is adequate to do his/her job: 1 if he/she is overeducated, and 2 if he/she is undereducated. Moreover, in relation to educational mismatch equation, two specifications have been considered in order to study different aspects of educational mismatch in the first job. In the first specification, independent variables could be classified in four different categories: personal variables (such as gender, nationality, and educational attainment); socioeconomic background (the employment status of both parents); the length of the search of employment and other factors, like the place of residence and the year when the interviewee left education. This basic model is extended in the second specification in which field of education of graduates is detailed, in order to analyse if the field of studies exerts any influence on the level of educational mismatch in the first significant job.

The interpretation of the coefficients in a multinomial model can be made through a log-odds model [20,21], where 
TABLE 1: Youth educational mismatch in the first significant employment (\%).

\begin{tabular}{lccc}
\hline & Total & Men & Women \\
\hline $\begin{array}{l}\text { Adequately matched } \\
\text { workers }\end{array}$ & 48.8 & 49.3 & 48.1 \\
$\begin{array}{l}\text { Overeducated } \\
\text { workers }\end{array}$ & 32.4 & 30.6 & 34.9 \\
$\begin{array}{l}\text { Undereducated } \\
\text { workers }\end{array}$ & 18.8 & 20.0 & 17.0 \\
\hline
\end{tabular}

Source: author's elaboration from Spanish Module on School to Work Transitions (2000).

the logarithm of the ratio of two probabilities is a function of the independent variables as follows:

$$
\operatorname{Ln} \frac{P_{j}}{P_{s}}=X\left(\beta_{j}-\beta_{s}\right)
$$

If we set the coefficients of the scategory to zero, then we just get

$$
\operatorname{Ln} \frac{P_{j}}{P_{s}}=X\left(\beta_{j}\right) .
$$

This approach provides an easy linear interpretation for the independent variables. This means that we can use the change in the odds ratio for category $j$ associated with a particular variable $X k$ examining $\exp (\beta j k)$. Therefore, for a one-unit change in $X k$, the odds of observing the relevant category versus the baseline category will change by $\exp (\beta j k)$.

Finally, given that educational mismatch can only be observed when the individual has obtained employment, the sample could present a selection bias. In line with similar studies (see, for instance, $[8,22,23]$ ) we estimate a sample selection Heckman two-step specification [24] to account for the possibility that working youth may not be a random subset of the whole youth in the sample. Thus, we first model the fact to get an employment using a probit equation (the probit equation includes gender, nationality, level of education, parents' level of education, parent's labour situation and occupation, number of siblings under 16, number of siblings over 16, search of employment, place of residence, and year of leaving education. The results are available upon request). These estimates are then used to construct a selection bias control factor, lambda, which is added to the explanatory variables in the model to estimate the educational mismatch in the first job.

\section{Results and Discussion}

The incidence of educational mismatch for the full sample of young workers is reported in Table 1 . These results confirm the existence of an important educational mismatch in the first significant employment, because only $48.8 \%$ of young people find a first employment in accordance with their educational level. Moreover, the percentage of overeducated individuals in the first job reaches $32.3 \%$, while the percentage of undereducated workers is $18.7 \%$. In order to explain this trend we should pay attention to the expansion of Spanish educational system in recent decades, the increase of youth levels of education, and the greater difficulties that this collective faces to obtain a job. Lastly, the results show that overeducation is more common among women, while undereducation presents a slightly higher incidence among men as Alba-Ramirez [5] shown in our labour market during the 1980s. The massive access of women to the educational system in Spain in the last three decades and the higher difficulties that they have to face in the labour market can help us to understand this fact.

Table 2 displays information about the incidence of educational mismatch by educational attainment. On the one hand, the highest percentages of adequately matched workers are among those with compulsory education $(67.8 \%)$ or university education $(53.3 \%)$. On the contrary, only $20 \%$ of those with secondary education or lower vocational training have a job matching their educational attainment. Moreover, the incidence of overeducation is above $55 \%$ for those with secondary education and vocational training. Finally, as one can expect, people with only compulsory education have the highest percentage of undereducated workers (31.8\%), whereas the proportion of undereducated workers among those with upper vocational training or university education is below $10 \%$. In any case, the information displayed in Table 2 shows that, far from being an isolated fact, education mismatch (and concretely, overeducation) is a frequent phenomenon that not only affects to university graduates, but it also hits people with lower levels of studies.

Table 3 shows the descriptive statistics of the variables included in the model whereas Table 4 shows the results of the multinomial model estimation. After deleting missing values, these exclusions left us with 6,909 individuals, of which 4,038 are men, and 2,771 are women. Tests of subsets of parameters show that our categorical variables are significant as a whole, although some specific categories may not be significant when considered separately. The tests and measurements of goodness of fit indicate that the model is well adjusted to the data.

According to the results, if everything else remains constant, women have a higher probability of being overeducated than men in the first job. This finding is in accordance with previous works such as Alba-Ramirez [5], Sloane et al. [22], Groot and Maassen van der Brink [25, 26], and Lassibille et al. [11]. This phenomenon could be explained if we consider that women could face some discrimination in the labour market [27], so it could contribute to increase the difficulties of finding a suitable job, in the first employment in Spain. Besides, the results show that Spaniards are less prone to be overeducated than foreigners. This result is in line with the works of Bratberg and Nilsen, and Kalter and Kogan [28, 29] which show the difficulties that foreign people face in the labour market.

As one might predict that educational variables provoke noticeable changes in probabilities, and it could be said that there is a strong relationship between the level of education and the match achieved in the first employment. Taking university graduates as a reference, it can be observed that the probability of being overeducated is higher for the rest 
TABLE 2: Educational (mis)match by level of education.

\begin{tabular}{|c|c|c|c|c|c|}
\hline & Compulsory & $\begin{array}{c}\text { Secondary } \\
\text { Postcompulsory }\end{array}$ & $\begin{array}{c}\text { Lower } \\
\text { vocational } \\
\text { training }\end{array}$ & $\begin{array}{c}\text { Upper } \\
\text { vocational } \\
\text { training }\end{array}$ & University \\
\hline $\begin{array}{l}\text { Adequately matched } \\
\text { workers }\end{array}$ & 67.8 & 20.3 & 19.8 & 38.1 & 53.3 \\
\hline $\begin{array}{l}\text { Overeducated } \\
\text { workers }\end{array}$ & 0.4 & 55.5 & 59.1 & 55.1 & 42.2 \\
\hline $\begin{array}{l}\text { Undereducated } \\
\text { workers }\end{array}$ & 31.8 & 24.2 & 20.4 & 6.8 & 4.5 \\
\hline
\end{tabular}

Source: author's elaboration from Spanish Module on School to Work Transitions (2000).

of individuals with lower educational attainment except for those with compulsory education. As regards the incidence of undereducation by level of education, we can see that the graduates are not affected by this kind of mismatch. Lassibille et al. [11] and Blázquez Cuesta [30] also find a similar result for the Spanish workers.

Regarding family characteristics, the results show that having a father with secondary studies or university studies reduces the probability of being overeducated, whereas the opposite effect is found when the father is a nonskilled worker or is unemployed. In other words, the father's education, his labour situation, and the family networks and connections in the labour market could promote the quality of the first employment achieved as shown by Rahona López [31].

In relation to the search for employment, it could be said that, a priori, the effect of search time on educational mismatch may be ambiguous [30]. On the one hand, we may argue that the length of the unemployment period adversely affects the outcome of the search process. Longer unemployment durations could be interpreted as an adverse productivity signal or as a signal of low human capital, consequently reducing the arrival rate of appropriate job offers. But on the other hand, longer search periods might improve the quality of the match. In this case, the results seem to support the first argument. We could observe that if the length of the search is less than six months, then the probability of being overeducated is reduced. However, individuals have a higher probability of being overeducated when the search of employment lasts more than one year.

Concerning other factors related to the economic cycle and local labour market conditions, it can be observed that leaving education after 1993 provokes an increase in the probability of being overeducated. This result could be related to the increase of the supply of highly educated young workers during the nineties. On the other hand, the findings show that the phenomenon of overeducation has a lower importance in La Rioja, Aragon, and Balers Islands, which are some of the regions that offer more employment opportunities for young people, whereas it has a higher incidence in Asturias and Extremadura, regions with high unemployment rates and where youths suffer the most serious problems in finding employment shortly after entering the labour market.

Finally, it is shown that selection bias is significant in the model, so this fact confirms that there are some individual characteristics that explain the attainment of the first employment and also the level of mismatch.

\section{Conclusions}

The main contribution of this paper is to study the transition to the labour market from a qualitative approach, analysing the match between the educational and the employment attainment. University education has often been blamed for the lack of adjustment between skills provided and demanded by the labour market. In that sense, focusing on the results of the Spanish case, we can conclude that overeducation is an extensive phenomenon during the first stages of careers for young people in Spain, and undoubtedly, young graduates are suffering from this problem from many years ago.

Nevertheless, according to the findings of the period analysed, the incidence of overeducation is higher among individuals with lower levels of studies with the exception of those with primary education. Therefore, it could be said that despite the expansion of Spanish University system has provoked a higher competition among graduates in the labour market, the fact of having a degree continues to provide some opportunities to individuals in occupational attainment not only in quantitative terms but also in qualitative terms.

To conclude, the results of this work confirm that youth educational mismatch in the first employment, far from being an isolated fact, is a frequent phenomenon, and it deserves to be considered by Spanish educational and labour policies. It is important to underline that this paper is focused on the 1990s decade before the present economical crisis began. Nowadays, the rate of unemployment among young people in Spain exceeds 50\%, and the time of job search has been expanded, so surely the problem of overeducation will be greater today than in the past according to our results that have shown that individuals have a higher probability of being overeducated when the search of employment lasts more than one year.

In our opinion, in Spain the so-called "lost generation" cannot find an adequately matched job, and their priority is to find employment, abroad or within our borders. In general, overeducated workers have higher mobility than other comparable workers. One reason for this is that they must relocate to improve their job match. The economic 
TABle 3: Descriptive statistics.

\begin{tabular}{|c|c|c|}
\hline Variable & Mean & $\begin{array}{l}\text { Standard } \\
\text { deviation }\end{array}$ \\
\hline Male & 0.562 & 0.496 \\
\hline Spanish & 0.991 & 0.092 \\
\hline Compulsory education & 0.408 & 0.357 \\
\hline Upper secondary education & 0.105 & 0.307 \\
\hline Lower vocational education & 0.108 & 0.310 \\
\hline Upper vocational education & 0.162 & 0.368 \\
\hline University education & 0.215 & 0.186 \\
\hline $\begin{array}{l}\text { Father is illiterate or has primary } \\
\text { education }\end{array}$ & 0.655 & 0.473 \\
\hline Father has upper secondary education & 0.093 & 0.291 \\
\hline Father has higher education & 0.109 & 0.316 \\
\hline Father is unemployed & 0.058 & 0.435 \\
\hline Father is inactive & 0.261 & 0.254 \\
\hline Father is a manager & 0.070 & 0.258 \\
\hline Father is a professional & 0.072 & 0.270 \\
\hline Father is a clerk & 0.079 & 0.479 \\
\hline Father is a skilled worker & 0.351 & 0.261 \\
\hline Father is a nonskilled worker & 0.073 & 0.236 \\
\hline 1991 & 0.099 & 0.298 \\
\hline 1992 & 0.115 & 0.309 \\
\hline 1993 & 0.116 & 0.326 \\
\hline 1994 & 0.123 & 0.330 \\
\hline 1995 & 0.124 & 0.327 \\
\hline 1996 & 0.116 & 0.329 \\
\hline 1997 & 0.113 & 0.317 \\
\hline 1998 & 0.100 & 0.312 \\
\hline 1999 & 0.095 & 0.299 \\
\hline Andalusia & 0.199 & 0.409 \\
\hline Aragón & 0.038 & 0.187 \\
\hline Asturias & 0.026 & 0.160 \\
\hline Baleares Islands & 0.024 & 0.148 \\
\hline Canary Islands & 0.056 & 0.224 \\
\hline Cantabria & 0.023 & 0.155 \\
\hline Castilla León & 0.083 & 0.276 \\
\hline Castilla La Mancha & 0.070 & 0.260 \\
\hline Catalonia & 0.104 & 0.297 \\
\hline Valencian Community & 0.085 & 0.276 \\
\hline Extremadura & 0.040 & 0.206 \\
\hline Galicia & 0.065 & 0.243 \\
\hline Madrid & 0.059 & 0.232 \\
\hline Murcia & 0.033 & 0.184 \\
\hline Navarre & 0.020 & 0.136 \\
\hline Basque Country & 0.052 & 0.222 \\
\hline La Rioja & 0.013 & 0.119 \\
\hline
\end{tabular}

Source: Spanish Module Data on School to Work Transitions (2000) and own elaboration.
TABLE 4: Determinants of educational mismatch in the first employment.

\begin{tabular}{|c|c|c|}
\hline \multirow{2}{*}{ Variables $^{\mathrm{a}}$} & \multicolumn{2}{|c|}{ Odds ratios } \\
\hline & $\begin{array}{l}\text { Undereducated/ } \\
\text { adequated }\end{array}$ & $\begin{array}{c}\text { Overeducated/ } \\
\text { adequated }\end{array}$ \\
\hline \multicolumn{3}{|l|}{ Personal data } \\
\hline Female & 0.814 & 1.810 \\
\hline Foreigner & 0.250 & 4.000 \\
\hline \multicolumn{3}{|l|}{ Education } \\
\hline $\begin{array}{l}\text { Compulsory } \\
\text { education }\end{array}$ & 8.786 & 0.004 \\
\hline $\begin{array}{l}\text { Upper secondary } \\
\text { education }\end{array}$ & 18.709 & 2.336 \\
\hline $\begin{array}{l}\text { Lower vocational } \\
\text { education }\end{array}$ & 15.478 & 2.204 \\
\hline $\begin{array}{l}\text { Upper vocational } \\
\text { education }\end{array}$ & 2.924 & 1.323 \\
\hline \multicolumn{3}{|l|}{ Father's education } \\
\hline $\begin{array}{l}\text { Secondary } \\
\text { education }\end{array}$ & 1.111 & 0.757 \\
\hline Higher education & 1.113 & 0.720 \\
\hline \multicolumn{3}{|l|}{$\begin{array}{l}\text { Father's employment } \\
\text { status }\end{array}$} \\
\hline Manager & 1.120 & 0.760 \\
\hline $\begin{array}{l}\text { Professional and } \\
\text { technical }\end{array}$ & 1.377 & 0.817 \\
\hline Skilled worker & 1.073 & 1.297 \\
\hline Nonskilled worker & 0.906 & 1.750 \\
\hline Unemployed & 0.917 & 1.982 \\
\hline Inactive & 1.117 & 1.051 \\
\hline \multicolumn{3}{|l|}{ Length of the job search } \\
\hline Less than 6 months & 2.057 & 0.262 \\
\hline $\begin{array}{l}\text { Between } 6 \text { and } 11 \\
\text { months }\end{array}$ & 0.740 & 0.858 \\
\hline More than a year & 0.527 & 1.990 \\
\hline \multicolumn{3}{|l|}{ Year of leaving education } \\
\hline 1992 & 0.772 & 1.247 \\
\hline 1993 & 0.561 & 1.150 \\
\hline 1994 & 0.738 & 1.613 \\
\hline 1995 & 0.746 & 1.797 \\
\hline 1996 & 0.501 & 1.818 \\
\hline 1997 & 0.795 & 2.408 \\
\hline 1998 & 0.278 & 3.321 \\
\hline 1999 & 0.259 & 8.065 \\
\hline \multicolumn{3}{|l|}{ Region } \\
\hline Aragón & 3.200 & 0.279 \\
\hline Asturias & 0.653 & 1.663 \\
\hline Balearic Islands & 1.726 & 0.277 \\
\hline Canary Islands & 1.794 & 0.502 \\
\hline Cantabria & 0.619 & 1.800 \\
\hline Castilla-León & 1.113 & 0.484 \\
\hline
\end{tabular}


TABle 4: Continued.

\begin{tabular}{|c|c|c|}
\hline \multirow{2}{*}{ Variables $^{\mathrm{a}}$} & \multicolumn{2}{|c|}{ Odds ratios } \\
\hline & $\begin{array}{l}\text { Undereducated/ } \\
\text { adequated }\end{array}$ & $\begin{array}{l}\text { Overeducated/ } \\
\text { adequated }\end{array}$ \\
\hline Castilla La-Mancha & 1.879 & 0.434 \\
\hline Catalonia & 1.821 & 0.386 \\
\hline $\begin{array}{l}\text { Valencian } \\
\text { community }\end{array}$ & 1.613 & 0.362 \\
\hline Extremadura & 0.863 & 1.447 \\
\hline Galicia & 0.968 & 0.651 \\
\hline Madrid & 1.735 & 0.475 \\
\hline Murcia & 0.999 & 0.605 \\
\hline Navarre & 1.794 & 0.365 \\
\hline The Basque Country & 1.873 & 0.324 \\
\hline La Rioja & 1.609 & 0.191 \\
\hline \multicolumn{3}{|l|}{ Selection bias } \\
\hline Lambda & 11.346 & 0.018 \\
\hline \multicolumn{3}{|c|}{ Measures and tests of goodness of fit } \\
\hline $\log L$ & \multicolumn{2}{|c|}{$-3.644 .46$} \\
\hline LR chi ${ }^{2}$ & \multicolumn{2}{|c|}{984.42} \\
\hline Prob $>$ chi $^{2}$ & \multicolumn{2}{|c|}{0.0000} \\
\hline Pseudo $R^{2}$ & \multicolumn{2}{|c|}{0.1190} \\
\hline$N$ & \multicolumn{2}{|c|}{6,909} \\
\hline
\end{tabular}

Hausman test Ho: differences in coefficients not systematic

\begin{tabular}{lcc} 
Omitted outcome & Overeducated & Undereducated \\
\hline $\mathrm{Chi}^{2}$ & 5.23 & 0.68 \\
Prob $>\mathrm{chi}^{2}$ & 1.000 & 1.000 \\
\hline
\end{tabular}

${ }^{\mathrm{a}}$ The omitted variables are male; Spanish; higher education; father is illiterate or has primary education; father is a clerk; no search for employment; leaving education in 1991; Andalusia.

In bold: Levels of signification $\geq 95 \%$.

Source: Spanish Module on School to Work Transitions (2000) and own elaboration.

precariousness of young people leaves aside the educational mismatch that we observe in good periods. Now, young people, especially women are job seekers with more intensity. Job match increases with age and experience (in-the-job training). The solution is to increase productivity of the Spanish labour market to be able to absorb the human capital.

\section{References}

[1] I. Berg, Education and Jobs: The Great Training Robbery, Praeger, New York, NY, USA, 1970.

[2] R. Freeman, The Overeducated American, Academic Press, New York, NY, USA, 1976.

[3] R. W. Rumberger, "The rising incidence of overeducation in the US labour market," "Economics of Education Review, vol. 1, pp. 293-314, 1981.

[4] J. Hartog and H. Oosterbeek, "Education, allocation and earnings in the Netherlands: overschooling?" Economics of Education Review, vol. 7, no. 2, pp. 185-194, 1988.
[5] A. Alba-Ramirez, "Mismatch in the Spanish labor market: overeducation?" The Journal of Human Resources, vol. 28, pp. 259-278, 1993.

[6] J. Allen and R. van der Velden, "Educational mismatches versus skill mismatches: effects in wages, job satisfaction and on-thejob search," Oxford Economic Papers, vol. 53, no. 3, pp. 434-452, 2001.

[7] H. Battu, C. R. Bellfield, and P. J. Sloane, "Overeducation among graduates: a cohort view," Education Economics, vol. 17, no. 1, pp. 21-37, 1999.

[8] P. Dolton and A. Vignoles, "The incidence and effects of overeducation in the U.K. graduate labour market," Economics of Education Review, vol. 19, no. 2, pp. 179-198, 2000.

[9] A. Chevalier and J. Lindley, "Overeducation and the skills of UK graduates," Journal of the Royal Statistical Society Series A, vol. 172, no. 2, pp. 307-337, 2009.

[10] P. J. Dolton and M. A. Silles, "The effects of over-education on earnings in the graduate labour market," Economics of Education Review, vol. 27, no. 2, pp. 125-139, 2008.

[11] G. Lassibille, L. Navarro Gómez, I. Aguilar Ramos, and C. de la O Sánchez, "Youth transition from school to work in Spain," Economics of Education Review, vol. 20, no. 2, pp. 139-149, 2001.

[12] J. Garcia-Montalvo and J. M. Peiro, Análisis de la sobrecualificación y la flexibilidad laboral, Capital humano y Empleo, Observatorio laboral de los jóvenes, Fundación Bancaja-Ivie, Valencia, Spain, 2009.

[13] R. W. Rumberger, "The impact of surplus schooling on productivity and earnings," Journal of Human Resources, vol. 22, pp. $1-50,1987$.

[14] J. Viera, "Education and earnings in Portugal in 1982, 1986 and 1992," Working Paper Tinbergen Institute 07-04-97, 1997.

[15] R. R. Verdugo and N. T. Verdugo, "The impact of surplus schooling on earnings. Some additional findings," Journal of Human Resources, vol. 24, no. 4, pp. 629-643, 1989.

[16] B. F. Kiker, M. C. Santos, and M. M. de Oliveira, "Overeducation and undereducation: evidence for Portugal," Economics of Education Review, vol. 16, no. 2, pp. 111-125, 1997.

[17] E. Cohn and Y. C. Ng, "Incidence and wage effects of overschooling and underschooling in Hong Kong," Economics of Education Review, vol. 19, no. 2, pp. 159-168, 2000.

[18] M. Mendes de Oliveira, M. C. Santos, and B. F. Kiker, "The role of human capital and technological change in overeducation," Economics of Education Review, vol. 19, no. 2, pp. 199-206, 2000.

[19] T. K. Bauer, "Educational mismatch and wages: a panel analysis," Economics of Education Review, vol. 21, no. 3, pp. 221-229, 2002.

[20] J. S. Long, Regression Models for Categorical and Limited Dependent Variables, Advanced Quantitative Techniques in the Social Sciences, no. 7, Sage Publications, Thousand Oaks, Calif, USA, 1997.

[21] G. S. Maddala, Limited-Dependent and Quality Variables in Econometrics, Cambridge University Press, 1983.

[22] P. J. Sloane, H. Battu, and P. T. Seaman, "Overeducation, undereducation and the British labour market," Applied Economics, vol. 31, no. 11, pp. 1437-1453, 1999.

[23] G. Di Pietro and P. Urwin, "Education and skills mismatch in the Italian graduate labour market," Applied Economics, vol. 38, no. 1, pp. 79-93, 2006.

[24] J. Heckman, "Selection bias as a specification error," Econometrica, vol. 47, pp. 153-161, 1979. 
[25] W. Groot and H. Maassen van der Brink, "Overeducation in the labor market: a meta-analysis," Economics of Education Review, vol. 19, no. 2, pp. 149-158, 2000.

[26] W. Groot and H. Maassen van der Brink, "Allocation and the returns to overeducation in the U.K.," Education Economics, vol. 5, pp. 169-183, 1997.

[27] M. M. Salinas-Jiménez, M. Rahona-López, and I. MurilloHuertas, "Gender wage differentials and educational mismatch: an application to the Spanish case," Applied Economics. Forthcoming.

[28] E. Bratberg and O. A. Nilsen, "Transitions from school to work: search time and job duration," TSER-STT, Working Paper 0599, Leo-Creseps, Orleans, France, 1999.

[29] F. Kalter and I. Kogan, "Ethnic inequalities at the transition from school to work in Belgium and Spain: discrimination or selfexclusion?" Research in Social Stratification and Mobility, vol. 24, pp. 259-274, 2006.

[30] M. Blázquez Cuesta, "Youth labour market integration in Spain: search time, job duration and skill mismatch," Spanish Economic Review, vol. 7, no. 3, pp. 191-208, 2005.

[31] M. Rahona López, "Equality of opportunities in Spanish higher education," Higher Education, vol. 58, no. 3, pp. 285-306, 2009. 

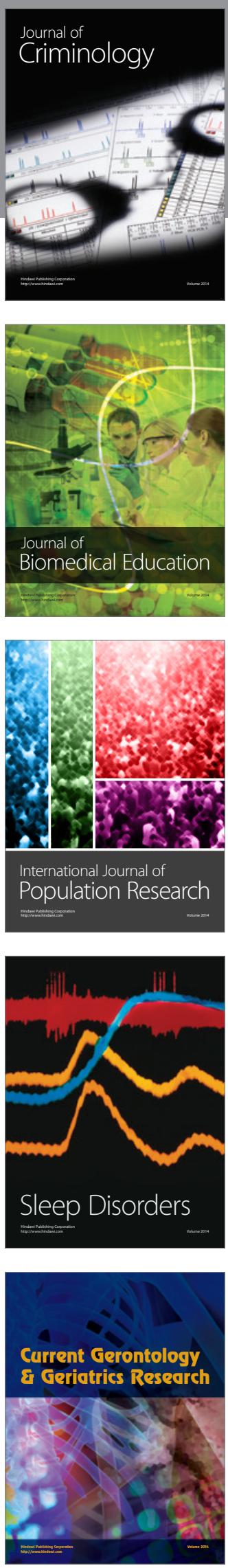
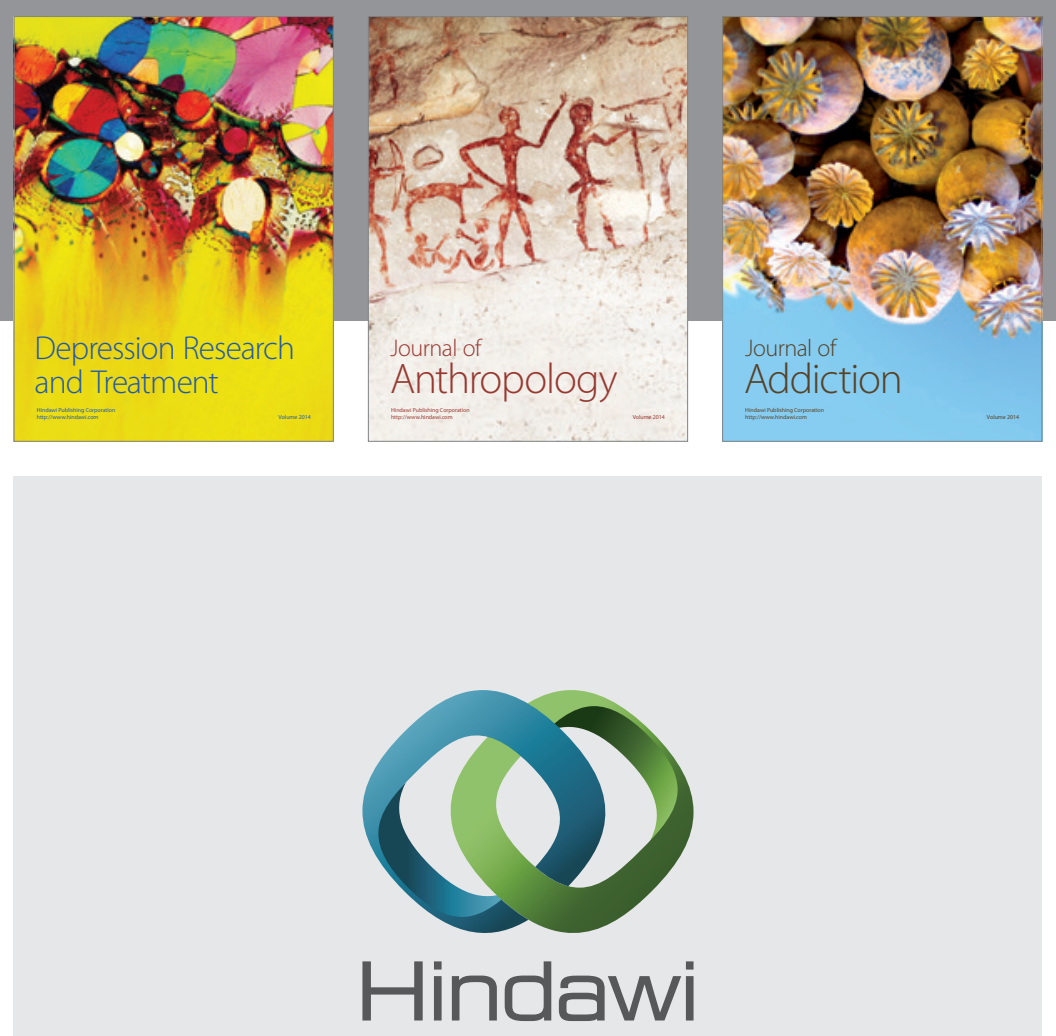

Submit your manuscripts at

http://www.hindawi.com

Child Development Research
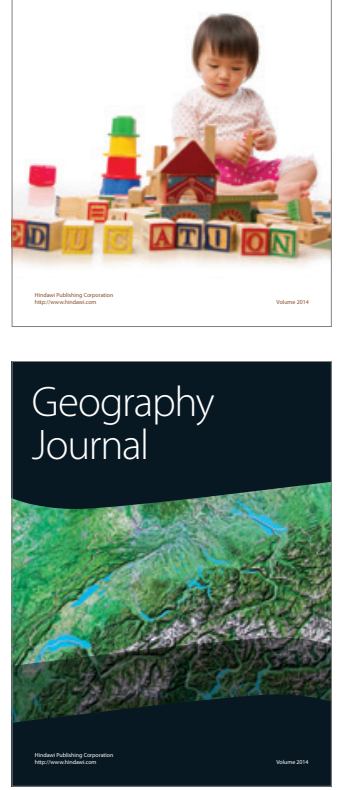

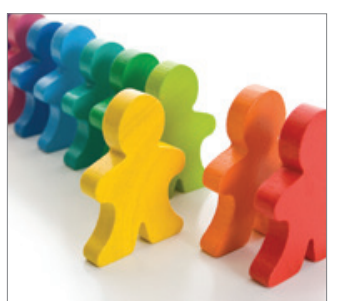

Autism

Research and Treatment
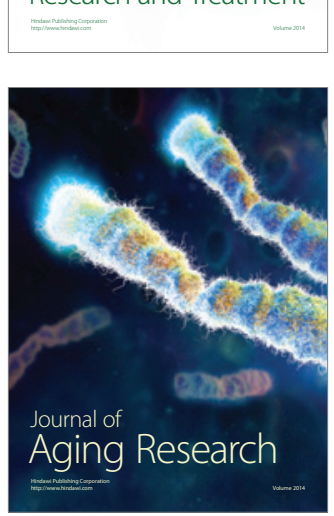
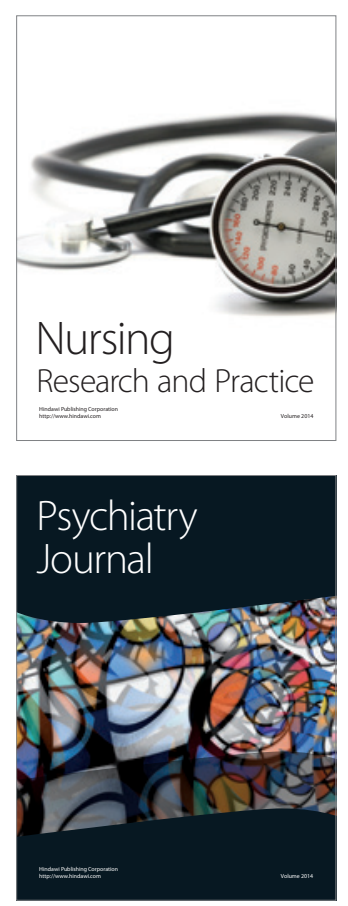
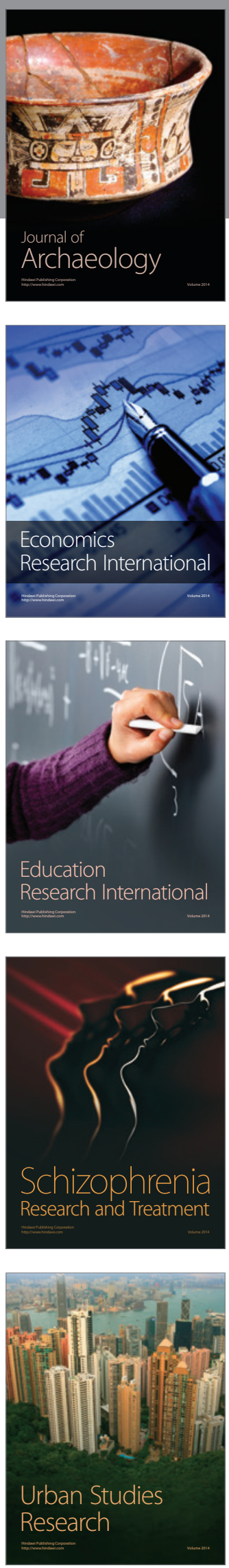